\title{
Management technologies of ensuring environmental protection as the territory development strategic priority
}

\author{
Olena Sushchenko ${ }^{1}$, Iryna Trunina $^{2}$, Oleksii $\mathrm{Klok}^{3}$ and Olha Loseva ${ }^{4, *}$ \\ ${ }^{1}$ D.Sc. (Economics), Professor, Simon Kuznets Kharkiv National University of Economics, Ukraine \\ ${ }^{2}$ D.Sc. (Economics), Professor, Kremenchuk Mykhailo Ostrohradskyi National University, Ukraine \\ ${ }^{3} \mathrm{PhD}$ (Economics), Simon Kuznets Kharkiv National University of Economics, Ukraine \\ ${ }^{4} \mathrm{PhD}$ candidate, Simon Kuznets Kharkiv National University of Economics, Ukraine
}

\begin{abstract}
The issues of changing the paradigm of strategic management of sustainable development and management technologies for environmental protection are considered on the basis of analysis of sustainable development strategies. The Eastern European countries such as Belarus, Bulgaria, Czech Republic, Hungary, Moldova, Poland, Romania, Slovakia and Ukraine were used as the focus group. The country profiles were made based on the management technologies used to protect the environment. The analysis of existing models of the quantitative estimation of efficiency of sustainable development with the purpose of revealing the indexes capable to assess the efficiency of management technologies were carried out. Based on the indexes of the Economic Performance Index, the strengths and weaknesses of each country were identified (based on 24 EPI indexes in general and EPI sub-indexes in particular). Proceeding from the results of the content analysis and the components of the economic efficiency index, the practice of strategic environmental protection management as a strategic priority of sustainable development is based on increasing resource efficiency and environmental awareness, development of eco-technologies and instruments of environmental management.
\end{abstract}

Key words: Management technologies, Environmental protection, Development strategic, Strategic priority.

\section{Introduction}

The effectiveness of the development of the country is influenced, among other things, by the decision-making model at the planning and management level. With the adoption of the program plan "Agenda 21", the prevailing decision-making systems proved to be inconsistent in the context of the transition to sustainable development, since they divided social, economic and political factors, while sustainable development implies their full integration [1]. Thus, the program plan, adopted in 1992, made significant adjustments of

\footnotetext{
*Corresponding author: olha.loseva@hneu.net
} 
the approaches to the strategic management of the territory development. As a result, the governments began to make significant institutional changes in order to ensure a systematic approach to the issue of sustainable development of the country. Also, the activities planned within the framework of «Integration of environment and development in decision-making» (Chapter 8), which describes the integration of environment and development of the policy, planning and management, assumed the adoption of national strategies for sustainable development.

The strategic management of the development of the administrative territory is a special kind of management that focuses on accomplishing the tasks set, registers the necessary steps to achieve an objective in the future. At the same time, the strategic management is the process that determines the sequence of actions to develop and implement a strategy. The sequence includes setting objectives, developing a strategy, identifying the necessary resources and maintaining communication with the external environment - all this al-lows you to achieve objectives. The strategy, as a key element in the strategic management in the context of this study, is considered as a set of measures for achieving sustainable development of the territory, which was developed on the basis of assessment and analysis of current development trends.

The ecological perspectives of sustainable development are based on ensuring proportionality between meeting the current and future needs of the society and natural conditions, taking into account the possibilities of using natural resources and landscapes. The awareness of the role of the environment on an equal footing with the economic and social component in ensuring sustainable development of the territory is an important stage on the way to reducing the negative human impact on the environment, overcoming global crises and poverty [2]. The key tasks to be resolved in the near future in this context are as follows: improvement of the quality of the environment, effective use of natural resources and waste management, maintenance of environmental stability, mitigation of climate change and adaptation to environmental changes caused by climate change.

At the present stage, it is impossible to ensure the sustainable development of each country without taking into account the environ-mental component. The global human impact on the environment leads to the realization of the need to attract new management technologies to ensure environmental protection. The transformation of approaches to strategic management of the territory is caused by an ever-increasing range of management technologies and improvement of territory management as a whole.

The objectives of this study are to identify common management technologies of protecting the environment and assess their effectiveness on the basis of the analysis of the national strategy for sustainable development.

\section{Data and Methods}

The protection of the environment as an element of sustainable development of the modern world is in the sphere of interests of the largest international organizations: the United Nations, the World Economic Forum, the European Commission, the Organization for Economic Co-operation and Development, the World Bank Group and so on.

According to the United Nations definition, the environmental protection is the activity of maintaining or restoring the quality of the environment aimed at preventing pollutant emissions or reducing the presence of pollutants in the environment by changing the characteristics of goods and services, consumption patterns, production methods, by recycling, preventing the degradation of the landscape and ecosystems, etc. [3].

Thus, the object of the research is the National Strategy for Sustainable Development as the fundamental document in the issues of strategic development of the country. The focus group of countries whose national sustainable development strategies were under study, 
was limited to a number of countries in Eastern Europe, such as Belarus, Bulgaria, Czech Republic, Hungary, Moldova, Poland, Romania, Slovakia and Ukraine.

The existing strategies, developed between 2001 and 2014, were analyzed at the first stage of the research. Table 1 contains a description of their main characteristics.

Table 1. National strategies for sustainable development in Eastern Europe

\begin{tabular}{|c|c|c|c|}
\hline Country & $\begin{array}{l}\text { Name of the } \\
\text { Strategy }\end{array}$ & Time Bound & Developer \\
\hline Belarus & $\begin{array}{l}\text { National Strategy for Sustainable } \\
\text { Development of the Republic of } \\
\text { Belarus }\end{array}$ & $2004-2020$ & $\begin{array}{l}\text { the research Institute of Economy } \\
\text { of the Ministry of Economy }\end{array}$ \\
\hline Bulgaria & $\begin{array}{l}\text { The National Development } \\
\text { Programme: Bulgaria } \\
2020\end{array}$ & 2012-2020 & the Council of Ministers \\
\hline $\begin{array}{l}\text { Czech } \\
\text { Republic }\end{array}$ & $\begin{array}{l}\text { The Czech Republic Strategy for } \\
\text { Sustainable Development }\end{array}$ & $\begin{array}{l}2004-2014 \\
(2030)\end{array}$ & $\begin{array}{l}\text { the Government Council for } \\
\text { Sustainable Development }\end{array}$ \\
\hline Hungary & $\begin{array}{l}\text { National Framework Strategy on } \\
\text { Sustainable Development } \\
\text { of Hungary }\end{array}$ & $2012-2024$ & $\begin{array}{l}\text { National Council for Sustainable } \\
\text { Development }\end{array}$ \\
\hline Moldova & $\begin{array}{|ll|}\text { the National Development } \\
\text { Strategy } 2020\end{array}$ & 2012-2020 & “Expert-Grup" Analytical Center \\
\hline Poland & 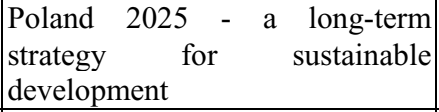 & $2000-2025$ & $\begin{array}{l}\text { Ministry of Investment and } \\
\text { Development }\end{array}$ \\
\hline Romania & $\begin{array}{l}\text { National sustainable development } \\
\text { Strategy } \\
2030\end{array}$ & 2008-2030 & $\begin{array}{l}\text { Ministry of Environment and } \\
\text { Sustainable Development, National } \\
\text { Centre for Sustainable } \\
\text { Development in Bucharest }\end{array}$ \\
\hline Slovakia & $\begin{array}{l}\text { The National Strategy for } \\
\text { Sustainable Development for the } \\
\text { Slovak Republic }\end{array}$ & $2001-2020$ & $\begin{array}{l}\text { Ministry of the Environment of the } \\
\text { Slovak Republic, United Nations } \\
\text { Development Program }\end{array}$ \\
\hline Ukraine & $\begin{array}{l}\text { The Strategy for Sustainable } \\
\text { Development "Ukraine 2020" }\end{array}$ & $2015-2020$ & $\begin{array}{l}\text { Administration of the President, } \\
\text { Executive Committee of the } \\
\text { Reforms and other }\end{array}$ \\
\hline
\end{tabular}

Source: Authors.

\section{Results}

\subsection{The profiles of the countries}

Belarus. In Belarus, the current status and changes in the environment are monitored and assessed on an ongoing basis in the context of environmental protection as a strategic priority of the country's development. The strategy implies the implementation of a set of measures aimed at gradual reduction of the anthropogenic impact on the environment, creation of conditions for building up and restoring the natural ecosystems of Belarus to an acceptable level. The country's environmental policy is based on the key ecological imperative, such as a man in the center of attention; environmental protection should become an integral part of the overall socio-economic development and cannot be considered in isolation from it; improvement of people's living standards. The features of management technologies of ensuring environmental protection include anti-crisis control, structural and technological adjustment [4].

Bulgaria. According to The National Development Program: Bulgaria 2020, the key aspect of the management of the territory on the path to sustainable development of the country is improving and integrating the national system of planning and management of 
regional development and the spatial planning and implementation of innovative solutions in the management practice. The conscious nature management is considered as one of the key components of sustainable development of the country, along with overcoming such problems as corruption, and structural and functional optimization of the government. The sustainable development strategy aims at combining environmental quality protection with ongoing economic growth in a way that is sustainable in the long term. On this basis, human capital plays a vital role in achieving the goals of sustainable development [5].

Czech Republic. Adaptive and crisis management, emergency planning formed the basis of "The Czech Republic Strategy for Sustainable Development" as main management technologies of environmental protection. The improvement of the quality of life of the population involves the introduction of technologies of active planting of greenery, reduction of the level of pollution and measures to improve the quality of spatial planning, systematic support of recycling. The ecological component in the system of sustainable development of the republic is expected to search for technologies for resolving the conflict between environmental protection (conservation of natural landscapes) and economic development (construction of new infrastructure facilities). The strategy implies the intensification of economic incentives for the transition to sustainable patterns of production and consumption and promotion of sustainable development of municipalities and regions [6].

Hungary. According to [7], sustainable development is a management method that emphasizes the long term, value preserving utilization of natural resources, enhancing prosperity without destroying diversity, complexity and ecosystem services. Prudent resources management and forward-looking management are a basis of development. The strategy implies the use of technologies aimed at achieving environmental awareness and sustainable lifestyle through the system of currently running programs assuming that in the future the ecological way of life will be perceived as a natural component. The development of knowledge and innovation-based nation is considered as an incentive to sustainability, while much attention is paid to improving the model of adoption of environmental solutions in the field of environmental protection.

Moldova. In view of the adoption of The National Development Strategy 2020, the paradigm for the development of the country's economy was substantially changed. The optimization of managerial policy in the matters of healthcare, culture, social security and environmental protection, are crucial for the country's sustainable development. As part of the strategy, the transition to green economic development is planned, including more effective management in the field of sustainable development by integrating and strengthening environmental aspects in all areas of the country's socio-economic development. The management technologies in this context imply significant institutional changes through reforms and modernization [8].

Poland. A long-term strategy for sustainable development of Poland is the structural basis of the country's development and a weighty basis for the implementation of specialized programs and plans for the development of human resources, regional development, including environmental protection, energy and climate policies, etc. The strategy is based on the principles of openness, unhindered access to information, active social communication and citizens' participation in the process of making managerial decisions. In view of the tendency of intensification of anthropogenic human impact on the environment, the strategy involves targeted technological measures to improve the quality of its components. By applying restrictive strategies towards sustainable development in the country, the assessment of the impact of adopted policy documents on the environment is made [9].

Romania. "National Sustainable Development Strategy Romania 2013-2020-2030" was developed on the basis of the program documents common to the member states of the 
European Union and covers the implementation of a number of tasks, such as: improvement of energy efficiency and extended use of renewable energy resources in order to mitigate the effects of climate change. At the current stage, the reduction of energy consumption is expected to be realized through active promotion of the Green House Program. Thus, the analysis of the country's sustainable development strategy in the context of environmental protection is testimony to the perception of sustainable development as the only true and rational perspective for the development of the society. The key management technologies of environmental protection within the framework of sustainable development are the application of anti-crisis management practices, the ability to anticipate the effects of climate change, to develop cross-sector contingency plans comprising portfolios of alternative crisis-management solutions in case of natural or man-made disasters [10].

Slovakia. The tasks formulated in [11] on the basis of the analysis of the world experience of strategic management of sustainable development are based primarily on ethical principles, global liability and capacity of a small country to provide assistance in solution of international problems. The tasks to be addressed within the frame-work of the environmental protection strategy are as follows: to overcome the consequences of prolonged unregulated use of limited natural resources, the use of management technologies that promote reasonable consumption, the improvement of long-term planning practice, the management of natural resources (special management system, in order to properly use, protect or avoid threatening of agricultural soil, waste management. The active application of the possibilities of environmental management and technologies of environmental legislation in Slovakia is directed at minimizing the risk factors of the environment, reducing the anthropogenic impact. The forecasting is considered as an opportunity to regulate economic and urbanizing activities for the rational use of resources and contribute to making the landscape management ecologically friendly.

Ukraine. It was found in the course of the retrospective analysis of the legal and regulatory framework of Ukraine in the context of the transition to sustainable development that the strategic management became a practice only in 2015 (The Strategy for Sustainable Development Ukraine 2020 [12]). Prior to this period, the unified strategy of Ukraine's sustainable development in various legal wordings was in the draft phase. The modern policy of sustainable development of Ukraine reflects the principle of parity of the economic, social and environmental components thus recognizing that long-term progressive development is not possible in conditions of environmental degradation. Consequently, there is an objective need to create a unified state system of management, regulation and control over compliance with resource-ecological standards, restrictions and requirements for environmental management and environmental quality. The management technologies are based on the complex approach, that is, the interests of the state are considered in the con-text of the paradigm of sustainable development of mankind. The strategy provides for strengthening of cross-sectoral integration, continuous interaction, coordination and cooperation of the authorities and society; mechanisms of mutual responsibility and assessment, a clear monitoring system that ensures the coordination of all government programs and activities with the objectives written in the Strategy.

\subsection{Indexes}

At the second stage, the analysis of existing models of quantitative assessment of the effectiveness of sustainable development is made to identify indexes that can assess the management technologies of environmental protection as the territory development strategic priority.

The study defines [13] the sustainable development strategy as a coordinated set of participatory and continuously improving processes of analysis, debate, capacity- 
strengthening, planning and investment, which integrates the economic, social and environmental objectives of society, seeking trade-offs where this is not possible.

Table 2 gives the main integral indexes which are used in the world practice of assessing the sustainability of development [14-23].

Table 2. Indicators of Sustainable Development

\begin{tabular}{|l|l|c|c|c|}
\hline \multirow{2}{*}{ Abbreviation } & \multicolumn{1}{|c|}{ Name of the Index } & \multicolumn{3}{c|}{ Sustainable Development } \\
\cline { 3 - 5 } & & Social & Environment & Economic \\
\hline ANS & Adjusted Net Saving & 1 & 1 & 1 \\
\hline EDP & Environmentally Adjusted Net Domestic Product & 0 & 1 & 1 \\
\hline EF & Ecological Footprint & 0 & 1 & 0 \\
\hline EPI & Environmental Performance Index & 0 & 1 & 0 \\
\hline ESI & Environmental Sustainability Index & 0 & 1 & 0 \\
\hline GCI & Global Competitiveness Index & 1 & 0 & 1 \\
\hline GGDP & Green gross domestic product & 0 & 1 & 1 \\
\hline GS & Genuine saving indicator & 1 & 1 & 1 \\
\hline HDI & Human Development Index & 1 & 0 & 1 \\
\hline ISEW & Index of Sustainable Economic Welfare & 1 & 1 & 1 \\
\hline SSI & Sustainable Society Index & 1 & 1 & 1 \\
\hline
\end{tabular}

Source: According to [14-23], authors.

The column "Sustainable Development" of Table 2 illustrates the inclusion of one or another component of sustainable development (social, environment, economic) in the index, where: rating 1 implies a direct relation of the indexes, included in the integral assessment, to this area of sustainable development; rating 0 implies the indirect relation of the indexes, included in the integral assessment, to this area of sustainable development.

The obtained data indicate that $90 \%$ of the studied indexes in one way or another assessing the sustainable development of the country take into account the state of the environment. At the same time, such indexes as Ecological Footprint, Environmental Performance Index, and Environmental Sustainability Index illustrate only the state of the environment as an element of sustainable development.

On the basis of the analysis of the resources that calculate the relevant indexes, we can claim that the most relevant data includes such indexes as the Environmental Performance Index (2018 indicators available) [17], the Global Competitiveness Index (2017) [23] and the Human Development Index (2016) [24], the Sustainable Society Index (2016) [22]. Thus, the comparative analysis of the countries under study is rational to make on the basis of the Environmental Performance Index.

According to the EPI calculation methodology, the key categories in which all 24 indexes are grouped are: air quality, water and sanitation, heavy metals, biodiversity and habitat, forests, fisheries, climate and energy, air pollution, water resources, agriculture [17]. Fig. 1 represents the specific weight of each indicator in the structure of the index. 

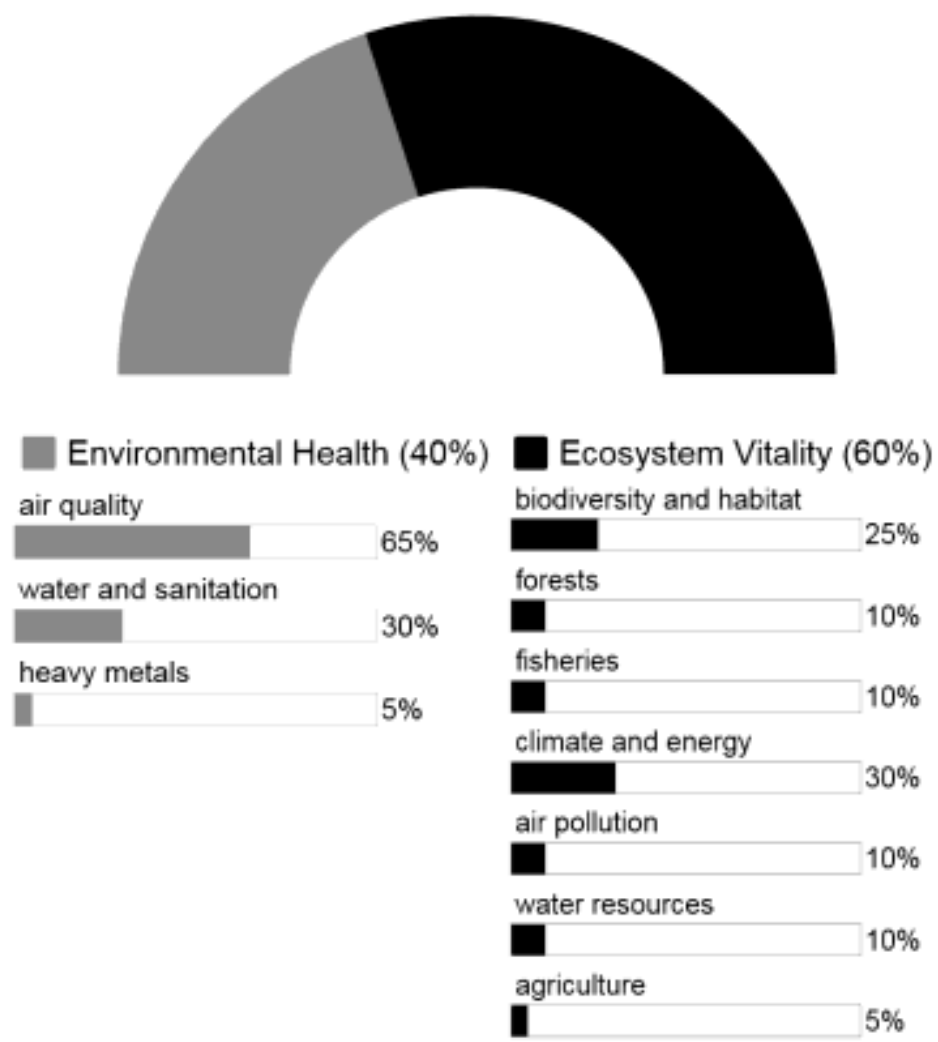

Fig. 1. Structure of indicators

Source: Authors.

The key sub-indexes for the calculation of EPI-2018 are Environmental Health (EH), Ecosystem Vitality (EV). The former is used to assess the degree of environmental impact on human health, the latter, in turn, focuses on indexes that reflect the biodiversity losses and climate change. Whereas the policy objective of Environmental Health has an empirical basis for deriving weights, the selection of weights in Ecosystem Vitality, is more subjective [17]. The sub-index values of EH, EV are shown in Table 3.

Table 3. EPI sub-index values

\begin{tabular}{|l|l|l|l|}
\hline \multicolumn{1}{|c|}{ Country } & \multicolumn{1}{c|}{ EPI } & \multicolumn{1}{c|}{ EH } & EV \\
\hline Slovakia & 70,60 & 63,87 & 75,08 \\
\hline Bulgaria & 67,85 & 69,60 & 66,68 \\
\hline Czech Republic & 67,68 & 68,69 & 67,01 \\
\hline Hungary & 65,01 & 57,67 & 69,90 \\
\hline Belarus & 64,98 & 69,55 & 61,94 \\
\hline Romania & 64,78 & 58,67 & 68,85 \\
\hline Poland & 64,11 & 58,71 & 67,72 \\
\hline Ukraine & 52,87 & 64,44 & 45,16 \\
\hline Moldova & 51,97 & 60,29 & 46,42 \\
\hline
\end{tabular}

Source: According to [17], authors.

The results obtained indicate that Slovakia is the absolute leader among the countries under study, according to the index (EPI $=70.60)$. The average index for the sample of countries was EPI $=63.32$ in view of the rather low indexes of such countries as Ukraine 
and Moldova. In the global ranking, Slovakia takes the 28th place in the world (from 180 countries), while Ukraine and Moldova in 2018 took 109th and 112th places respectively.

Since the task of the study is to assess the effectiveness of management technologies directed at protecting the environment, we consider it expedient to identify the strengths and weaknesses of each country (based on 24 EPI indexes in general and EPI sub-indexes in particular) for the purpose of subsequent search of the interconnection of the environmental support technologies and quantitative indexes of environmental efficiency provided by the strategy. The range of problems of environmental efficiency lies in the sphere of reducing pressure on the environment and, as a result, on human health, stimulating the viability of ecological systems and stable management of natural resources, including counteraction to the climate change, the burden of economic activity on the environment, the effectiveness of state policy in the sphere of ecology.

Table 4 includes the assessment of the strengths and weaknesses of activities for the protection of the environment in Eastern Europe. Based on the data received, such global problem as air pollution is the most vulnerable place in the country's ecological efficiency (in particular, Romania, Poland, Slovakia, Bulgaria and Czech Republic are the countries affected by this problem most of all). The solution of the problems connected with biodiversity conservation and habitat conservation requires finding new management approaches for such countries as Belarus and Moldova. For Ukraine, the most urgent problem is overcoming rapid negative climate changes. Opposite from the point of view of Ukraine's positions in the rating is the experience of Slovakia and Romania, where technologies for overcoming climate pollution and reducing greenhouse gas emissions are effectively working.

Table 4. Countries Rank

\begin{tabular}{|l|l|l|l|l|l|}
\hline \multicolumn{1}{|c|}{ Country } & $\begin{array}{c}2018 \\
\text { EPI }\end{array}$ & EH & EV & \multicolumn{1}{|c|}{ The best index position } & The worst index position \\
\hline Slovakia & 28 & 89 & 3 & Climate \& Energy (9) & Air Quality (133) \\
\hline Bulgaria & 30 & 66 & 24 & Biodiversity \& Habitat (23) & Air Quality(89) \\
\hline Czech Republic & 33 & 69 & 22 & Heavy Metals (5) & Air Quality (97) \\
\hline Hungary & 43 & 107 & 12 & Agriculture (5) & Air Quality (146) \\
\hline Belarus & 44 & 67 & 48 & Water Resources(18) & Biodiversity \& Habitat (114) \\
\hline Romania & 45 & 105 & 15 & Climate \& Energy (15) & Air Quality (136) \\
\hline Poland & 50 & 104 & 18 & Biodiversity \& Habitat (6) & Air Quality (144) \\
\hline Ukraine & 109 & 87 & 139 & Heavy Metals (15) & Climate \& Energy(143) \\
\hline Moldova & 112 & 102 & 127 & Agriculture (35) & Biodiversity \& Habitat (160) \\
\hline
\end{tabular}

Source: Authors.

Air pollution is a global problem affecting people in all countries and socio-economic groups. The unsatisfactory condition of the environment, primarily air pollution, causes an increase in morbidity and mortality among the population. On the basis of the experience of Western European countries, the most common management technologies in this respect can be considered:

- air management,

- air protection,

- monitoring and evaluation of climatic parameters and air quality,

- implementing clean and affordable modern technologies inside homes,

- furthering public awareness on air pollution,

- encouraging scientific progress in regards to air pollution and its subsequent effects on health and climate change.

The most common practice in the issues of energy and climate is the adaptation of the country to changing climatic conditions, which is due to anthropogenic influence. The 
strategies for sustainable development of the countries from the focus group may imply the following:

- improvement of energy efficiency and expanded use of renewable energy resources,

- investments into the energy sector,

- use of potential of renewable climatic resources (solar and wind energy),

- regulation of economic and urbanizing activities,

- ecologisation of landscape management.

In order to preserve the existing biodiversity, which is affected by such negative influence factor as urbanization, the presence of heavy and energy industries in the country, the intensification of agriculture and forestry, mass tourism, the countries strive to level out the impact of noise, emissions and other factors of impact on the biodiversity of the territory. This aspiration is manifested in sustainable development strategies in the following way:

- conservation and strengthening of life-supporting, self-regulatory, self-purifying and self-supporting natural mechanisms,

- adaptive management, for a reduction in the number of endangered varieties and species of plants and animals and the preservation of biodiversity,

- elaborating and implementing action plans with regards to endangered animal and plant species,

- forest fire prevention and sustainable utilization management of the forest resources.

\section{Discussion and Conclusion}

Thus, based on the content analysis of the strategies, we may state that the main objective of biodiversity conservation is to ensure the reasonable use, reproduction and protection of animal and plant species, their genetic and biological diversity and renewal of natural ecosystems, while maintaining regional and global environmental balance and production possibilities of the biosphere.

The characteristic feature of sustainable development strategies in the context of environmental protection as a strategic priority at the level of separate territories is the continuous adjustment and cyclical renewal of the strategy in the dialogue with stakeholders to ensure comprehensive sustainable development. At the present stage, the key importance is given to the following technologies:

- rise of resource efficiency (effective management of resources throughout their life cycle), which in turn is closely dependent on eco-innovations, changes in the structure of production and consumption),

- rise of awareness (conscious nature management is considered as one of the key components of protection of environment), while the practice of creating a competitive environment in the form of ratings is widespread;

- development of ecological technologies (green technologies); along with the growing popularity of the practice of the use of renewable energy sources, there is an active support of funding research, subsidies, eco-labeling and government "green" procurements;

- effective ecological management, which includes new methods of recording, monitoring and reporting on environmental pollutants and wastes, using the best available information and technology. 


\section{References}

1. Agenda 21, Earth Summit, The United Nations Program of Action from Rio, 1992 [online]. Available at:

https://sustainabledevelopment.un.org/content/documents/Agenda21.pdf (1992)

2. Environmental protection expenditure, European Commission [online]. Available at: http://ec.europa.eu/eurostat/web/environment/environmental-protection-expenditure (2018)

3. Glossary of Environment Statistics, Studies in Methods, Series F, No. 67, United Nations, New York (1997).

4. National Strategy for Sustainable Development for the Period to 2020 of the Republic of Belarus, The National Sustainable Development Commission of Belarus. Minsk, p. 76 [online]. Available at:

http://www.by.undp.org/content/dam/belarus/docs/OON_sMall\%20-\%201.pdf (2004)

5. The National Development Programme: Bulgaria 2020 [online]. Available at:

https://www.eufunds.bg/archive/documents/1357828564.pdf (2018)

6. The Czech Republic Strategy for Sustainable Development, Prague [online]. Available at: https://www.mzp.cz/C125750E003B698B/en/czech_republic_strategy_sd/\$FILE/KMCR_SDS_eng-20041208.pdf (2004)

7. National Framework Strategy on Sustainable Development of Hungary [online]. Available at:

https://www.stakeholderforum.org/fileadmin/files/National\%20Framework\%20Strategy $\% 20$ on $\% 20$ Sustainable $\% 20$ Development.pdf (2018)

8. National Development Strategy 2020. Moldova 2020 [online]. Available at: http://particip.gov.md/public/files/Moldova_2020_ENG1.pdf (2018)

9. Strategia zrównoważonego rozwoju polski do roku do roku 2025 [online]. Available at: http://snep.edu.pl/sms/materialy/strategia\%20zrownowazonego\%20rozwoju\%20polski\% 20do\%20roku\%202025.pdf (2018)

10. Romanian National Strategy for Sustainable Development - Horizons 2013-2020-2030. Ministry of Environment and Sustainable Development, Bucharest [online]. Available at: http://sdgtoolkit.org/wp-content/uploads/2017/02/National-Sustainable-

Development-Strategy-of-Romania-2013-2020-2030.pdf (2008)

11. National Strategy For Sustainable Development For The Slovak Republic [online]. Available at: https://www.thegef.org/sites/default/files/ncsadocuments/Slovakia_NSSD_Final.pdf (2001)

12. On the Strategy of sustainable development "Ukraine - 2020": Decree of President of Ukraine from 01.12.2015 № 5/2015 [online]. Available at: http://zakon3.rada.gov.ua/laws/show/5/2015?nreg=5\%2F2015\&find $=1 \&$ text $=\% \mathrm{~F} 1 \% \mathrm{~F} 2$ $\% \mathrm{E} 0 \% \mathrm{~EB} \& \mathrm{x}=0 \& \mathrm{y}=0$ (2015)

13. Dalal-Clayton B., Bass S. Sustainable Development Strategies: a resource book. OECD \& UNDP [online]. Available at: https://www.sd-network.eu/pdf/resources/DalalClayton, $\% 20$ Bass $\% 20(2002) \% 20-\% 20$ Sustainable $\% 20$ Development $\% 20$ Strategies $\% 20$ \%20A\%20Resource\%20Book.pdf (2001)

14. World development indicators 2007 [online]. Available at: http://documents.worldbank.org/curated/en/336241468138277212/World-developmentindicators-2007 (2007) 
15. Environmentally Adjusted Net Domestic Product, The United Nations Statistics Division [online]. Available at:

https://unstats.un.org/unsd/environmentgl/gesform.asp?getitem=467 (2018)

16. Ecological Footprint, Global Footprint Network, Advancing the Science of Sustainability [online]. Available at: https://www.footprintnetwork.org/ourwork/ecological-footprint (2018)

17. Environmental Performance Index [online]. Available at: https://epi.envirocenter.yale.edu (2018)

18. Socioeconomic Data and Applications Center, Environmental Sustainability Index [online]. Available at: http://sedac.ciesin.columbia.edu/data/collection/esi (2018)

19. Green gross domestic product, Green Growth Knowledge Platform [online]. Available at: http://www.greengrowthknowledge.org (2018)

20. Genuine saving as a sustainability indicator, The World Bank [online]. Available at: http://documents.worldbank.org/curated/en/908161468740713285/Genuine-saving-asa-sustainability-indicator (2000)

21. F. M. Chelli, M. Ciommi, G. Chiara, Index of Sustainable Economic Welfare: A comparison of two Italian regions. Procedia - Social and Behavioral Sciences, 81, 443448, (2013)

22. Sustainable Society Index [online]. Available at: http://www.ssfindex.com (2017)

23. The Global Competitiveness Report 2017-2018, World Economic Forum Annual Meeting [online]. Available at: https://www.weforum.org/reports/the-globalcompetitiveness-report-2017-2018 (2017)

24. Human Development Reports, United Nations Development Programme [online]. Available at: http://hdr.undp.org/en (2018)

25. N. V. Nenkov, M. M. Petrova, Y. Dyachenko, Intelligence Technologies in Management and Administration of Justice. 3rd International Multidisciplinary Scientific Conference on Social Sciences and Arts SGEM 2016 Conference Proceedings, 385-392, (2016)

26. N. Nenkov, O. Sushchenko, Y. Dyachenko, Role of chief information officer within the system of human resource development in the service organizations (tourism). Economic Annals-XXI, 165(5-6), 97-103, (2017). 